\title{
Oppfølgingsprosjekt - Tiltak mot selvmord $2000-2002$
}

Ved N ils Petter Reinholdt

Prosjektbeskrivelsen for oppfølgingsprosjektet: "Tiltak mot selumord 2000 - 2002" er nylig publisert og distribuert. Hovedmålsetningen for den treårige prosjektperioden er å styrke helsetjenestens kompetanse og tilbud til mennesker som er i selvmordskrise, samt iverksette tiltak for å forebygge selvmord i utsatte grupper.

Driften ved det nasjonale kompetansesenteret, Seksjon for selvmordsforskning og -forebygging ved U niversitetet i 0 slo, og tre regionale ressursmiljøer videreføres. Sentrene i N ord- og M idt-N orge forankres fortsatt ved henholdsvis $\AA$ sgård sykehus og N T N U Trondheim. For å stimulere til økt aktivitet i helseregion Vest har Rogaland, H ordaland og Sogn og Fjordane fått tildelt midler til treårige prosjektstillinger. De som innehar stillingene, vil sammen med en representant for fylkeslegene i de tre fylkene utgjøre det regionale ressursmiljøet i helseregion Vest.

Prosjektets delmål er formulert slik:

\section{Sikre gode oppfølgings- og behandlingsrutiner for mennes- ker som er i selvmordskrise}

En betydelig oppgave for de regionale ressursmiljøene vil her være å bistå fylkeskommuner og kommuner $\mathrm{i}$ arbeidet med å utvikle kompetanse og rutiner.

\section{Økt og systematisk forskning}

I dette ligger forskningsoppgaver rettet inn mot definerte satsingsområder, spredning av forskningsbasert suicidologisk kunnskap, og videreutvikling av den suicidologiske databasen som er opprettet ved Seksjon for selvmordsforskning og -forebygging.

\section{Systematisk}

\section{kunnskapsformidling}

A rbeidet med å styrke suicidologifagets plass ved de relevante utdanninger på universitets- og høgskolenivå skal gis fortsatt prioritet. Det etableres et toårig videreutdanningstilbud i suicidologi, og de første studentene vil bli tatt opp våren 2001. O pplæringsprogrammet VIVAT inkluderes som en del av formidlingsstrategien. Dette medfører at en i prosjektperioden vil få en landsomfattende spredning av kurset "Intervensjon ved selvmordsfare". Informasjonsarbeidet gis prioritet regionalt, og nasjonalt blant annet gjennom fortsatt utgivel se av tidsskriftet "Suicidologi". Det vil fortsatt bli holdt regionale nettverkssamlinger.

Følgende områder/grupper er definert som særskilte satsingsområder i prosjektperioden:

- Barn og unge

- Etterlatte ved selvmord

- A rbeidsplassen

- Eldre

- H omofile og lesbiskes situasjon

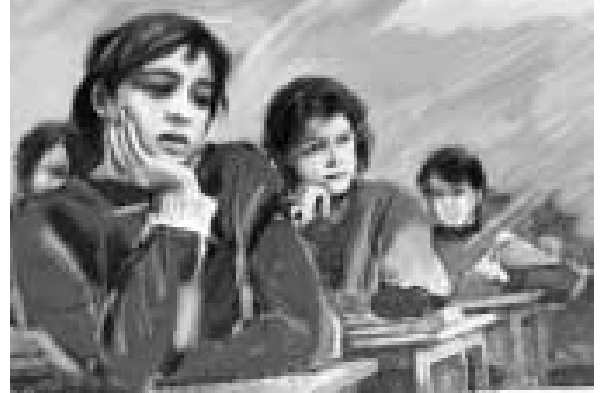

Barn og unge er definert som særskilte satsingsområder i prosjektperioden 2000 - 2002

Prosjektet forankres i Statens helsetilsyn, A vdeling for spesialisthel setjeneste. Det ansettes prosjektleder i deltidsstilling, og styringsgruppen videreføres med sammensetning som under $\mathrm{H}$ andlingsplan mot selvmord. Referansegruppe for prosjektet oppnevnesi løpet av høsten 2000.

U nder forutsetning av Stortingets budsjettbehandling er den årlige rammen for prosjektet kr 7700000.

For nærmere detaljer henvises det til prosjektbeskrivelsen: "O ppføl gingsprosjekt - Tiltak mot selvmord".

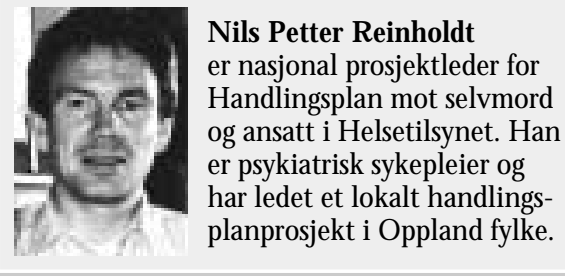

